\title{
THE INFLUENCE OF EMPLOYMENT MODES ON EMPLOYEE TURNOVER AND AGRI-BUSINESS PERFORMANCE: A CASE FOR HUNYANI FARM IN THE ZVIMBA DISTRICT, ZIMBABWE
}

\author{
${ }^{1}$ Kudakwashe Svotwa, \\ ${ }^{2}$ Ezekia Svotwa, \\ ${ }^{3}$ Thandiwe Rugube
}

\begin{abstract}
${ }^{1}$ Number 6 Rainham Road, Willowvale, Harare Zimbabwe
${ }^{2}$ Chinhoyi University of Technology, Crop Science Department, Box 724, Chinhoyi, Zimbabwe

${ }^{3}$ National University of Science and Technology, Box Ac 939 Ascot, Bulawayo, Zimbabwe
\end{abstract}

Corresponding author

${ }^{1}$ svotwakcc@gmail.com

2esvotwa2@gmail.com

${ }^{3}$ thandiwe.gwatsvaira@nust.ac.zw

\begin{abstract}
The labour intensive nature of Zimbabwean agriculture demands that farmers meet excessive labour requirements, at the same time keeping labour costs as low as possible to guarantee profits and achieve maximum business performance. This study, carried through a questionnaire survey, at the Hunyani Matura Farm, in the Zvimba district of Zimbabwe between from October 2017 to March 2018, investigated the effect of employment mode on turnover and agri-business performance. Data collected from the participants, was compared with the information from secondary source documents. From the results temporary workers performed better than permanent workers and they cited problems of low wages, poor working conditions, high work targets, inequality in work allocation, job insecurity and constant shuffling. Temporary workers had higher turnover and turnover intentions than permanent workers. Temporary employment mode had a positive effect on agri-business performance. This study recommends the use of permanent employment mode on key positions like forepersons, stores persons and supervisors, and temporary employment mode on general farm tasks, while seasonal contracts were seen good for skill demanding operations such as tobacco seedbed establishment, tobacco reaping and curing and grading. A ccareful selection of employment modes reduces inequalities and unhealthy attitudes at work and improves on farm business performance.
\end{abstract}

Keywords: employment mode, farm labour requirements, temporary labour, labour costs, staff turn-over, agri-business performance

(JEL Classification: Q12 )

\section{INTRODUCTION}

Today's business is carried out in an environment where the need for efficiency calls for employers to cut employment costs by shifting to manageable temporary and freelance workers (Huber, 2004:239). Economic hardships in Zimbabwe have weakened profitability and hence capacity of employers to hire labour. The high rates of unemployment have also led to a vast supply of labour and a general willingness for the unemployed to accept any form of employment and the conditions that come with it (Pasurai, 2017). Recent developments in the agricultural industry indicate general shift towards more temporary and informal forms of employment that the permanent forms due to the seasonal nature of the operations (Collins and Krippner, 1999:511). Of late, the 
agricultural industry has not been performing to its best in Zimbabwe (Zimbabwe Agricultural Statistics, 2016).

The past employment practices under colonialism in Zimbabwe were oppressive to the blacks and were characterized by racial discrimination (Ncube, 2000:164). There were no jobs for which defined wages or remuneration were paid to farm workers (Aldrich et al. 2000). The employment system aimed at ensuring continuous supply of cheap labour, in the farms. According to the ILO(1978) the black people were not considered as employees and could not form or be part of any forum that determined employment conditions, and were not protected by law. The agricultural industry was mainly characterized by labour casualisation because of the seasonality of operations which caused fluctuating labour demands.

The post-independence period saw a boom in commercial agricultural production (Zimbabwe Agricultural Statistics, 2016), which enabled the employment of a significant number of reliable permanent workers. However, the droughts which followed in 1982/1983 and 1987/1988 cropping seasons disturbed agricultural activities (Maiyaki, 2010:4160).These droughts, together with the introduced minimum wages caused farm employers to be more capital intensive and contributed to the fall in agriculture's share of total formal employment from $35 \%$ to the 1990 figure of $24.3 \%$ (Ncube, 2000:165). This is because employment protection laws made it impossible to adjust the workforce levels in accordance with the economic downturns that followed (Ncube, 2000). Since the law allowed dismissal of casual workers, most companies started employing casual employees that could be laid off easily. This shift to flexible employment modes was also noted by (Chiripanhura and Makwavarara, 2000:23), who noted an increased tendency towards casualisation of labour, especially in large commercial scale agriculture where the percentage of people employed on full time basis went down from a peak of $75 \%$ in $1981-1982$ to $47 \%$ in 1998 . In 1989 the government gave back the liberty to the employer to lay off workers in an effort to achieve flexibility of the labour market (Ncube, 2000:163). Most employers laid off majority of permanent workers and the use of flexible employment modes increased as employers hired and fired at their convenience (Thata, 2015).

The land reform program implemented in the year 2000 to address the colonial imbalances in land ownership, resulted in the sudden exit of white farmers from commercial farms without compensation (Selby, 2005). By November 2002, an average of 85 percent of the farms had either halted or significantly scaled-down operations and reduced capacity to employ Sachikonye (2003), with a shift towards temporary employment modes (Wandera, 2011).

Permanent employment occurs when employees work on a regular basis for a stipulated average number of hours per week and the contract ties them to one organization for an unspecified length of time (George and Chattopadhyay, 2015). Temporary employment on the other hand is whereby employees are hired for a speci冋ed period of time (e.g., one month) (Ton and Huckman, 2008). "Short term employment" or part time is commonly defined as a job where the individual does not have an explicit or implicit contract for long term employment, the short term nature of the job being recognized by both parties (Nardone et. al., 1997). Some employers now employ temporary workers to fit in key managerial positions (Ongera and Juma, 2015:4).

Whilst the agricultural industry surely makes use of permanent employment modes, there are a number of temporary employment options for employers. Seasonal work is performed only at certain times of the year (Labour Act, 28:01; ILO, 2015; Filmer and Fox, 2014). Seasonal contracts are formulated in a way to guarantee employment continuously throughout the busy farming season. In casual work, an employee is engaged by an employer for not more than a total of six weeks in any four consecutive months (Labour Act, 28.01). Under casual employment, employers only make sure that the total number of days for which each casual worker is taken does not exceed six weeks in a consecutive period of four months and employers take casual workers only on the specific days needed (Jayne and Ameyaw, 2016); Yeboah and Jayne, 2016). Fixed term employment is defined by Ongera and Juma, (2015) as employment contracts for which the date of termination is pre-determined at the beginning of the contract and agreed on by either party to the contract of employment. According to the ILO $(2015: 23)$ these type of contract are less popular in the agricultural sectors of most countries. In Zimbabwe farm employers are allowed to employ fixed term contract workers for nine months contracts which are renewable six times (statutory instrument 16 of 2017).

Task work or piece rate forms of employment are ones under which payment is entirely determined by output per day (Jayne and Ameyaw, 2016). The targets can be daily, weekly or task based, completion of which guarantee employees a certain pre-promised reward (Jayne and Ameyaw, 2016:10). Mostly the payment could be flexed depending on size of tasks, where employer tries to encourage workers to put an extra effort for an extra reward (Jayne and Ameyaw, 2016:14).

Turnover is the average of total number of employees newly recruited and departed within a period, divided by the average number of employees over the period (Harris et. al., 2002:3). Temporary job contracts lead to increase in involuntary turnover rate by default and the opposite is true for permanent jobs contracts, all things being equal (Wandera, 2011: 193).

In general, business performance is defined as the operational ability to satisfy the desires of the company's major shareholders (Smith and Reece, 1999; Colase, 2009). In Zimbabwe most agri-businesses are still labour intensive because of the slow rate of farm mechanization (Zimbabwe Agricultural statistics, 2017), performance of an agricultural operation is deemed to be affected by such things as labour costs, employee productivity and 


\section{performance.}

The effect of employment on profitability is mostly centered around its effects on cost. Whilst decreasing employee costs within an organization is a critical aspect of strategic human resource management with regard to competitive global market (Allen et al., 2016) as cited by (Wandera, 2011:189), many researchers have conflicting arguments about whether the use of temporary employment modes have a positive or negative effect on profits. George et al. (2015) advocates that it is less costly and more flexible to employ on temporary basis than on permanent basis because the use of temporary employment modes, allows firms to adjust their workforce to business-cycle fluctuations at relatively low termination costs (Nielen and Schiersch, 2014).

Hunyani Matura Farm is currently being run as a Strategic Business Unit (SBU) for the School of Agricultural Sciences and Technology. It farm has two sections which are the livestock section where there are cattle, sheep, goats and chickens, the later comprising the indigenous, broilers and layers; and the crop section which grows maize, soya beans, pastures trees, tobacco, potatoes (CUT, 2017). The crop section also runs a horticulture production which sees production of horticultural and field crops. It is also used as an experimental platform for agricultural research. The university finance department is the one that funds Hunyani Matura Farm projects and the accounts department thereof prepares the financial statements regarding income and expenditure. Hunyani Matura Farm, like any business unit is faced with a goal to make profit and maximize business performance. The labour intensity of operations puts on its shoulders the need to balance labour requirements with the need to lower costs. Whilst flexible employment modes are an attractive option, the need for experienced, trained and reliable people who uphold the production culture at the farm also cannot be denied. The maximum level, to which Hunyani Matura Farm can use of temporary employment modes before the disadvantages start to outweigh the benefits, is not clear. Given a labour intensive operation, employee's feelings and perceptions about the employment modes and their effect on turnover are also to be considered. There is need to ascertain how the overall performance of the agri-business is affected and come up with the best way to combine various employment modes.

A lot of research has been conducted which acknowledges the existence of various forms of employment and their effect on employee turnover and productivity, yet these have not been contextualized to the Zimbabwean economy. Furthermore, little has been done to contextualize studies to the country's agribusiness sector, where $70 \%$ of Zimbabwe's employment is derived (Maiyaki, 2010). Rogovsky (2005) has revealed the need to permanently employ the right people, for profitability and continued success of any business, citing employee turnover as contributor to quality decline and increase in training costs. Generally the number or percentage of workers who leave an organization and are replaced by new employees becomes high, the costs of training new workers also increases and generally, high employment turnover is accompanied by quality decline as the new employee still has to learn efficient ways of doing their job. However, in the Zimbabwean agri-business context, economic conditions and seasonality of operations make it more costly to keep a large number of full-time employees, necessitating flexible employment modes (Pasurai, 2017). On the other hand, some studies reveal that the use of nonstandard workers is not cost effective in, when other costs like productivity turnover are considered (Nollen and Axel, 1996). The study brings out how various modes of employment can be combined to maximize performance of a seasonal agri-business within a developing economy like Zimbabwe.This study sought to investigate the effect of employment modes on employee turnover and agri-business Performance using Hunyani Matura Farm as a case study. It is hypothesized in this research that the employment mode has a significant influence on employee turnover, employee performance and farm business performance.

\section{METHOD}

\section{Site description}

This study was conducted at the Hunyani Matura Farm in the Mashonaland West Province of Zimbabwe. Hunyani Matura Farm is in the Zvimba District. The Hunyani Matura Farm is situated $120 \mathrm{~km}$ Northwest of Harare, just after Manyame river on the north eastern end of the main campus (CUT Weekly, 2016:1) and was given to the university under the land reform program in the year 2005 . The farm area is 550 hectares. Hunyani Matura Farm is in the Natural Region IIb area of Zimbabwe, which is characterized by mean annual rainfall of approximately $600-850 \mathrm{~mm}$ yr-1 and mean daily temperature of $26^{\circ} \mathrm{C}$ (Surveyor General, 2002). The coordinates of the Research Farm, Teaching and Extension Unit are: $17^{\circ} 21^{\prime} 0.00^{\prime \prime} \mathrm{S}, 30^{\circ} 12^{\prime} 0.00^{\prime \prime} \mathrm{E}$ (Latitude:-17.3500; Longitude: 30.2000). The site is at an elevation of approximately $1.158 \mathrm{~m}$ above sea level. The site soils on the study site are well drained clay loam soils. In general the area in which Hunyani Matura Farm is located is a hub for agriculture, with soils and climate suitable for commercial agriculture that involves production of maize, soya, tobacco and several vegetable crops

\section{Data collection}

\section{Population of the study}

The population of the study was personnel from Hunyani Matura Farm, that is, the permanent employees (13) and the temporary employees (at least 60 at a given time). The total population was then made up of 13 permanent workers and a fluctuating number of temporary employees. This is because farm operationsare busier at certain times of the year than the others.The Farm Manager was purposively chosen because he is the key person who plans 
production, and has the knowledge about the fluctuation of activities and the labour requirement trends. The farm manager presided over the activities of both permanent and temporary workers. The livestock section had three (3) permanent employees and these were chosen owing to their small number. There were five (5) permanent field workers who were chosen since they are the people who work with different temporary employees on daily basis. There was one (1) farm driver on a permanent contract who was chosen. There were also two (2) security guards employed on permanent basis, one for the livestock section and one for the crop section. The one for the crop section (where the bulk of casual workers work) was purposively chosen. There is also an employment register keeper employed on permanent basis.

A total of forty (40) casual workers were randomly chosen because of their large number $(120-150$. The study therefore relied both on purposive sampling in some areas, targeting knowledgeable respondents who are aware of the employment policies, the management of employment contracts and the profit and productivity and performance trends being explored, to promote a deep understanding of phenomena under investigation (Mhlanga, 2008; Yin, 2009); and random sampling on other instances like the selection of temporary workers because of the size and homogeneity of the sub population.

\section{Sampling Strategy}

This study utilized stratified sampling where participants were first grouped into the following subpopulations; Hunyani Matura Farm management, permanent workers, temporary workers. The study then made use of purposive sampling, targeting knowledgeable respondents including managers, and random sampling on the selection of temporary workers.

Figure 1: Triangulation of data collection methods Source: Adapted from Jona (2015), Research Methodology in Journalism and Media Studies, (IJM 5201)

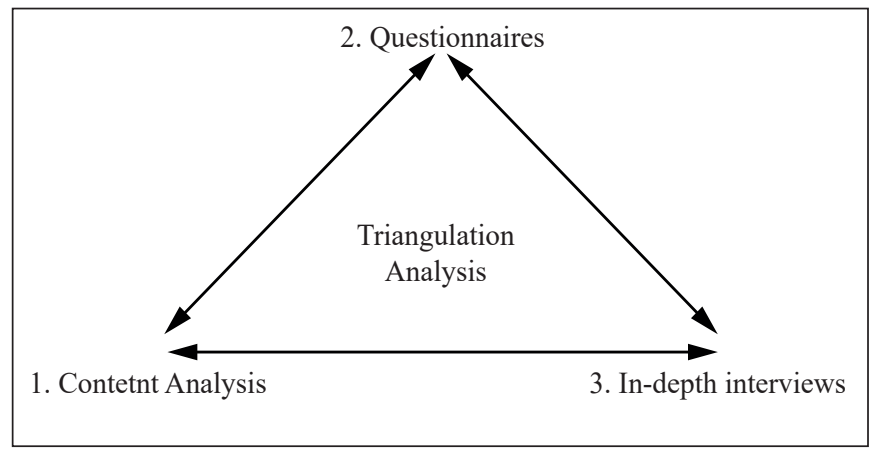

The triangulation of data collection methods (Figure 1) was used as an attempt to explain more fully, the richness and complexity of human behaviour by studying it from more than one standpoint (Cohen and Manion, 2005). The aim was to increase credibility and validity of results, under the expectation that either two or three of the selected methods will produce similar results. Triangulation was also applied to guarantee that the shortcomings of one data collection method would be addressed by the strength of the other.

\section{Questionnaires}

Structured questionnaires would help the subjects to explain the interaction between the phenomena under study in confidence without the interference of the researcher (Kawulich, 2005). The questionnaire consisted of 25 questions designed to obtain information on social biographic data of age, sex, tenure and level of education of workers and, also information on work allocation, ability to meet targets, perception on compensation and wok relationships.

\section{In-depth Interviews}

The interview technique was most applicable within this study because interviews, according to Yin, (1994) offer the possibility to gather knowledge from participants who are familiar with the research topic. Conducting interviews made it possible to clarify vague answers by probing and allow observation of non-verbal expressions which made it easier for researcher to understand verbal responses. Aspects like relationship among workers, standard allocation of work by managers as well as the general work atmosphere. The interviews allowed respondent to express themselves freely and reduce the risk of incorrect information, the presence of the interviewer may have influenced the manner in which the questions answered.

\section{Content analysis of Secondary Source Documents}

Secondary data is gathered and recorded by someone else prior to the current project (Constantine: 2001). Existing information included internal records like employment registers, production and financial records. Whilst the method could provide even unwanted data, it is cost effective and rules out the involvement of a third party, at the same time providing readily analyzed data which is incorporated easily into the research.

\section{Data Presentation and Analysis plan}

The data was input into a spread sheet and Microsoft excel tool were used to analyse the data. Chi-square test of association was used to bring out relationships among different variables, while graphs were plotted using Microsoft excel. This study also used pattern matching of findings against a backdrop of literature reviewed. According to Carolyn J. and Knight J. (2002), pattern matching is a useful technique for linking in - depth interview data to theoretical propositions guiding the study. Thematic analysis was used for data presentation and analysis through constructing themes that are related to the four objectives of the study. Thematic analysis, according to Jensen (1982: 247) enables the study to compare, contrast, and abstract all constitutive elements of meaning with ease, thus making the analysis orderly, concrete and smart.

\section{RESULTS}




\section{Descriptive statistical evaluation of the different models}

The employment modes at Hunyani Matura Farm and the provisions under them

Hunyani Matura Farm engaged workers under permanent, fixed term and casual employment contracts.

\section{Permanent Employees}

The permanent workers consisted of general hands, drivers and farm managers. The permanent general hand employees had a basic salary of at least US $\$ 400 /$ per month. All permanent workers were engaged for 8 hours a day and their contract provided for payment of overtime and night shift allowances. Permanent workers had access to free health services in cases of injuries on the job, and were also provided transport to and from work. The permanent employees got personal protective clothing and had access to loan facilities both from the university.

\section{Casual employees}

Casual employees' contracts were not engaged on form of written contact and Ewere paid on a daily rate of US\$3. Some casual workers had night shifts in irrigation and tobacco curing for the same daily rate of US $\$ 3$.The casual employees were also given access to medical supplies for injuries on the job and transport to and from work. In some cases a casual employee would bring their working tools like hoes, axes, mattocks and picks to work. The casual workers were taken on daily basis for performance of specific tasks. There is no provision for safety clothing for the casual workers.

\section{Fixed term contract employees}

All fixed term contracts were 6 months long for such roles as drivers and security guards. The fixed term contract workers were provided with personal protective clothing, were paid at the rate determined by the National Employment Council of Zimbabwe and also got transport and medical services, but their contracts do not provide for any form of night duty allowance.

The Hunyani Matura Farm sometimes provided farm produce for preparation of lunch and breakfast for all the workers.

\section{The effect of employment modes on employee turnover}

Ninety percent $(90 \%)$ of the casual workers had been engaged for a period of less than a year, whilst all the permanent workers had been at the farm for at least 3 years. Most (67\%) of these workers did not have the basic five ordinary level subject passes. A high turnover intention was identified, with $72.5 \%$ of the casual employees indicating expectation to work at Hunyani Matura Farm till they find "a permanent job". Sixty seven (67.5\%) percent of the casual workers found work uninteresting and $22.5 \%$ found work neither interesting nor uninteresting and the rest (10\%) indicated that work at the farm was "interesting". However, all permanent workers found work "interesting" at the farm and none indicated an intention to leave Hunyani Matura Farm (Figure 2).

Figure 2: Employee responses on whether they found work interesting at Hunyani Matura Farm

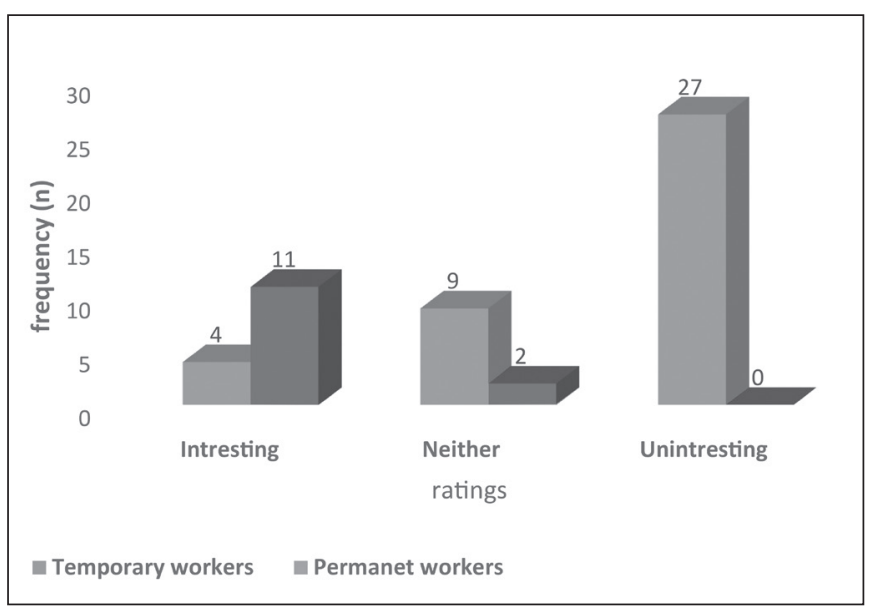

Source: Primary data

Eighty nine (89\%) percent of those who found work uninteresting cited too high daily targets with an inequitable pay rate, poor working conditions and the insecurity of not being guaranteed of a job the very next day," as the major reasons why they found work uninteresting citing "big workloads, lack of personal protective clothing and the chasm between casual and permanent worker wage rates" as the major reasons.

The participants were also asked to rate the working conditions at Hunyani Matura Farm (figure 4.3).The modal rating for the permanent workers was the " $5=\operatorname{Good"~}(n=8)$, while that for the temporary staff was the " $5=$ Poor" $(n=13)$. A chi-square test of association between mode of employment and the rating of working conditions was highly significant $(\mathrm{p}<0.05)(\mathrm{Ho}=$ no association) (Figure 3).

Figure 3: Employee ratings on working conditions at Hunyani Matura Farm

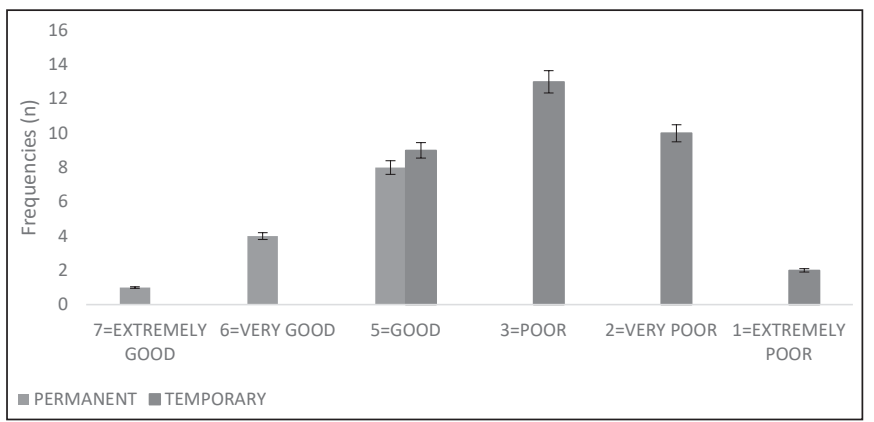

Source: Primary data

Ninety two $(92.5 \%)$ percentof the temporary employees felt there was a mismatch between their expectations and what they finally found upon getting hired. Eighty seven (87.5\%) percent expected to secure a permanent employment within 6 months of engagement, while $65 \%$ (26) expected regular wage increases. Hunyani Matura Farm was not an employer 
of choice to most temporary employees $(98 \%)$ because the conditions of employment and wages were perceived better at neighbouring farms. The perceived better conditions in neighbouring farms included "a pay rate of US $\$ 4.5$ per day; workers pick up glean produce from the field; daily targets achievable; always engage on seasonal contracts; always provide protective clothing". Some $85 \%$ of the casual workers indicated that they had no other source of income besides working at Hunyani Matura Farm.

\section{Effect of employment modes on performance of the Agri-business Unit}

Hunyani Matura Farm was also assessed in relation to the aspects proposed by Colase (2009:) as cited by (Achim and Borlea, 2012), which are profitability, growth, productivity, efficiency, competitiveness and productivity. In an effort to facilitate an accurate and coherent data presentation, analysis and interpretation of the research findings the researcher adopted the use of tables by Mapolisa (2015) to highlight main themes and their sub-themes, together with their substantiating statements. Researcher first highlights perception of managers and the farm director then tries to back this up with what the farm reports revealed and the questionnaires revealed. A close examination of Hunyani Matura Farm reports was done to bring out production, profit, sales and labour costs trends.

Table 1: Theme(s) and sub-themes regarding performance of $\mathrm{Hu}-$ nyani Matura Farm in relation to the employment under various modes comparatively, basing on the perspectives of Managers

\begin{tabular}{|c|c|c|}
\hline Theme(s) & Sub-themes & Substantiating Statements \\
\hline \multirow[t]{3}{*}{$\begin{array}{l}\text { Perfor- } \\
\text { mance of } \\
\text { the } \\
\text { business } \\
\text { operation }\end{array}$} & 1. Profitability & $\begin{array}{l}\text { “It's far much cheaper to work with } \\
\text { temporary employees at US\$3 per day that } \\
\text { permanent staff at US } \$ 400 \text { per month" } \\
\text { Manager B "Assuming they come to work } \\
30 \text { days a month, temporary employees } \\
\text { earn } 90 \text { dollars a month that's significantly } \\
\text { lower than the US } \$ 400 \text { for permanent } \\
\text { workers.... honestly no one can argue } \\
\text { with such a reduction in labour costs ..." } \\
\text { Manager A }\end{array}$ \\
\hline & $\begin{array}{l}\text { 2. Employee } \\
\text { performance }\end{array}$ & $\begin{array}{l}\text { "If you really want to get things done on a } \\
\text { time scale, the casual workers can get things } \\
\text { done... permanent workers have a sense of } \\
\text { superiority over the casuals, you can only get } \\
\text { results from them if you give them a super- } \\
\text { visory task which feeds their ego" Manager } \\
\text { A“...you give them (temporary employees) } \\
\text { daily targets you are guaranteed they put their } \\
\text { best to it because their working day is com- } \\
\text { plete when the task is done" Manager B } \\
\text { "...temporary workers perform better than } \\
\text { permanent workers because first they want to } \\
\text { continue being taken for the job and secondly } \\
\text { the day is only marked in the register if the } \\
\text { given task is completely done.", Foreman }\end{array}$ \\
\hline & 3. Growth & $\begin{array}{l}\text { "we have tremendously grown in terms of } \\
\text { scope of activities, market share and sales } \\
\text { revenue ever since we flexed our employment } \\
\text { contracts" Manager A }\end{array}$ \\
\hline
\end{tabular}

Source: Adopted and adapted from Mapolisa 2015:160

\section{Business growth}

In an effort to analyze performance in terms of growth, researcher came up with a few sub themes under the theme "growth" (table 3).

Table 2: Theme(s) and sub-themes regarding growth at Hunyani Matura Farm in relation to sales revenue, market share and scope of activities, basing on the perspectives of Managers

\begin{tabular}{|c|c|c|}
\hline Theme(s) & $\begin{array}{l}\text { Sub- } \\
\text { theme }\end{array}$ & Substantiating statements \\
\hline \multirow[t]{3}{*}{$\begin{array}{l}\text { Business } \\
\text { growth }\end{array}$} & $\begin{array}{l}\text { Sales } \\
\text { Revenue }\end{array}$ & $\begin{array}{l}\text { "By October } 2017 \text { daily sales from horticulture } \\
\text { were averaging US } \$ 400 \text { per day... by December } \\
2017 \text { the highest recorded amount of daily sales } \\
\text { was US } \$ 1700 \text { at times when we were selling po- } \\
\text { tatoes." Manager A } \\
\text { "In } 2016 \text { we generated an amount of almost } \\
\text { US } \$ 66000 \text { in revenue from maize only and } 43 \\
000 \text { revenue from tobacco up from less than } \\
\text { US } \$ 1000 \text { which was received from each of the } \\
\text { crops in the previous year... before } 2015 \text { we } \\
\text { could hardly achieve sales of } 20000 \text { from all } \\
\text { farming activities." Manager B }\end{array}$ \\
\hline & $\begin{array}{l}\text { Market } \\
\text { share }\end{array}$ & $\begin{array}{l}\text { "Most tobacco farmers in Mash West who used } \\
\text { to get seedlings from Kutsaga Research station } \\
\text { seeds in Harare now come to Hunyani Matura } \\
\text { Farm for tobacco seedlings (US\$9000). We have } \\
\text { Customers coming to buy our cabbages and but- } \\
\text { ternut from as far as Kariba, Mhangura, Karoi, } \\
\text { Banket and Chegutu... we now supply maize to } \\
\text { GMB... we also sell produce to the University } \\
\text { community..." Manager A'We now supply lo- } \\
\text { cal Supermarkets with green beans, carrots, } \\
\text { butternut etc. Most vendors in Chinhoyi come } \\
\text { to buy direct form our field and we also have a } \\
\text { lorry that carries farm produce to the Chinhoyi } \\
\text { Market place. Our crop section also supplies the } \\
\text { livestock section with maize for livestock feed... } \\
\text { truth is we never used to produce enough to meet } \\
\text { all such demand before } 2015 \text { " Manager B }\end{array}$ \\
\hline & $\begin{array}{l}\text { Scope of } \\
\text { activities }\end{array}$ & $\begin{array}{l}\text { "If we had not switched to employment of more } \\
\text { temporary workers we would not have been able } \\
\text { to increase the both the number of our crops and } \\
\text { the scale at which we grow them... We managed } \\
\text { to increase our horticultural projects from } 1 \text { hect- } \\
\text { are to a total area of } 30 \text { ha... we introduced to- } \\
\text { bacco( } 30 \text { ha) and also increased maize area from } \\
10 \text { to } 35 \text { ha" Manager A } \\
\text { "We have successfully increased number of } \\
\text { crops and area without any staff shortages... } \\
\text { actually our activities are expanding every year } \\
\text { since we started hiring under flexible modes...we } \\
\text { are even growing gum trees" Manager B } \\
\text { "...by reducing our labour cost we were able to } \\
\text { support expansion of more farm activities there- } \\
\text { fore we increased our area of almost every crop } \\
\text { we used to grow and also introduced new crops } \\
\text { such that we now make better utilisation of our } \\
\text { capacity... we are considering taking baking back } \\
\text { the portion of land we previously leased to the } \\
\text { Chinese" Farm Director }\end{array}$ \\
\hline
\end{tabular}

Source: Adopted and adapted from Mapolisa 2015:160

Table 3 below shows increases in area of commercial maize from 10ha to more than three times as much from 2015 to 2017. Tobacco area also increased form less than a hectare of experimental crop in 2015 to a peak of 30ha by 2017. Hunyani Matura Farm also introduced soy bean at ten hectares in 2017. 
Table 3: Summary of Crops grown, Area, Yield per hectare, Total Output and Sales Revenue realized from 2015-2017 based on Hunyani Matura Farm production and sales records

\begin{tabular}{|l|c|c|c|c|c|c|c|c|c|}
\hline & \multicolumn{3}{|c|}{ Maize } & \multicolumn{3}{c|}{ Tobacco } & \multicolumn{3}{c|}{ Soy Bean } \\
\hline Year & 2015 & 2016 & 2017 & 2015 & 2016 & 2017 & 2015 & 2016 & 2017 \\
\hline $\begin{array}{l}\text { Total area } \\
\text { (ha) }\end{array}$ & 10 & 20 & 35 & 0.5 & 30 & 22 & 0 & 0 & 10 \\
\hline
\end{tabular}

Source: Secondary data

\section{Employee performance}

Eighty five (85\%) percent of the temporary employees felt the temporary workers performed better than the permanent workers. Both farm managers concurred and surprisingly almost half (46\%) of the permanent workers admitted that temporary employees performed farm duties better than permanent employees citing that

- "The permanent workers boast over their salaries higher wages that that of temporary workers ...they spend the day loitering and shunning the work"

- "When given a combined task with temporary workers, the permanent workers drag down because they don't lose anything if they fail to finish ..."

- "When tasks were completed early temporary workers would be free ...permanent workers always knock off at $5 \mathrm{pm} "$

- "its better to make them work separately"

Figure 4: Employee responses on ability to meet daily targets at the Hunyani Matura Farm

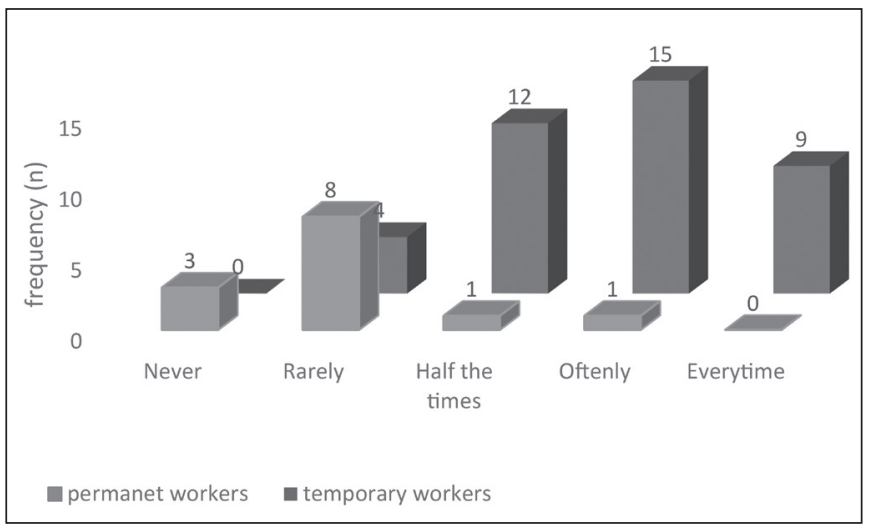

Source: Primary data

The modal rating for the permanent workers was the "Rarely" $(n=8)$, while that for the temporary staff was the "Often" ( $\mathrm{n}=15)$. A chi-square test of association between mode of employment and the ability to meet daily targets was highly significant $(\mathrm{p}<0.05)(\mathrm{Ho}=$ no association), showing that there is a relationship between employee performance and employment mode. It can also be noted that the ratings for the temporary workers are skewed towards the positive ratings and the opposite is true for the permanent workers' ratings.

\section{DISCUSION}

The basic salary for farm permanent workers of at least US $\$ 400$ was significantly above the National Employment Council (NEC) rates and the rates in the collective bargaining agreement between farm workers and farm employers of US\$3 a day or US\$75 per month. The 8 hours per day, for which the permanent workers work, the overtime and night shift allowances, were in line with Zimbabwean Labour Act (28:01). Workers at Hunyani Matura Farm had access to free health services at the Chinhoyi University of Technology clinic in cases of injuries on the job. Providing transport for the permanent workers was on the other hand an expense but on the other it ensures workers are at work on time every day to avoid unnecessary delays. Providing safety clothing for the permanent workers was not only in line with basic safety requirements, but it also ensures that the workers can work with free minds without fearing for their health. However there was need to improve on safety for workers working in tobacco bans, to avoid respiratory problems.

The use of unwritten contracts meant there were no stipulated task definitions, durations of employment or conditions thereof. The casual employeeswere paid on a daily rate of US $\$ 3$, as by then required by both NEC and under the collective bargaining agreement betweenfarm workers and agricultural employers in 2016.

Defining the working day by a specific a task was a reliable performance management technique. However, since a day was deemed completed when the task assigned was completed, regardless of the time taken to complete it or the time of day the task gets finished, the workers might be vulnerable to exploitation in cases when tasks could be increased without a corresponding increase in wages. There was need to standardise tasks to avoid perceptions of exploitation and keep good attitude towards work.

Provision of access to medical supplies for injuries on the job to casual employees was not only an ethical employment practice, but could make the casual workers feel important and as part of the farm "family". Whilst providing transport to and from work for the farm workers was an additional expense, it also ensures reliable supply of manual labour on a continuous basis and timely start of daily operations. Although the unwritten requirement for casual employees to bring their working tools to work reduces risk of theft of equipment by employees, doing this without giving an allowance for the tools, could be viewed as an unethical employment practice since the employer was paying the same wage for both the labour and his tools. The use of casual employees whose contracts were subject to renewal on daily basis, gave rise to the need to closely monitor work registers to ensure compliancewith labour provision in terms of maximum period of engagement for temporary workers. The lack of provision for safety clothing for the casual workers could be demotivation.

The use of fixed term employees provided a certain level of job security as compared to temporary workers. 
The provision of farm produce for meals at work also ensured workers were well fed and had strength to perform tasks (Parker 1994).

The high turnover intentions at the Hunyani Matura Farm were similar to the findings of other researchers elsewhere (Wandera 2011), and could be due to absence of a legal obligation to stay in the absence of any written contract. The simplicity of the farm tasks for which Hunyani Matura Farm hires casual employees, made it easier to replace without incurring significant training costs. It also explained the lack of effort by farm management to control turnover levels.

The Lack of skills, basic educational qualifications or total illiteracy among the temporary workers gave the leeway to farm management to keep wages to the minimum. Without any special skill, the casual workers were easily hired, fired and replaced without much disturbance to the flow of work (Costa and Silva, 2007). According to Nonaka and Takeuchi (1995) the constant hiring actually allowed employers to gain from new knowledge that comes in new employees.

The significantly high levels of dissatisfaction among casual workers could be because of the cited heavy workloads, low wages, lack of protective clothing, general mismatch between expectations form work and what eventually materialized, and unequal treatment as compared to their male counterparts. According to the Equity theory workers who perceive a breach of the general "equal work for equal pay principle" may end up sabotaging work, or stealing to achieve a perceived balance between what their work efforts and what they get from work (Fisher, 1948). Workers who fail to strike a psychological balance end up leaving or intending to leave (ILO, 2015). According Wandera (2011) short term employment has underlining certain characteristics that make short term workers more prone to work related strain which causes dissatisfaction, poor performance (Rousseau and Libuser, 1997) and high intention to leave.

Matura Farm has strict a performance management policy for temporary employees which ties their output to reward. On the other hand the fact that there is no extra incentive to permanent workers, tied to the completion of daily targets and no punishment resulting from not meeting the daily target as opposed to the assertion by Taylor (1996) whose scientific management theory linked compensation to output. The general contentment, relaxation and less anxiety in permanent employees could be a result of satisfaction derived from being paid above national rates, provided safety clothing, less supervision in terms of targets and feelings superiority to the temporary counterparts.

The increase in market share could be emanating from ability to satisfy higher levels of demand which comes from increase in capacity to employ more labour in the form of cheaper temporary contracts, to support expansion. Reduction of permanent workers and replacement of these by cheaper temporary employees results in release of funds for expansion and increased capacity to employ more labour to support the expansion. Hence the ability to meet higher demand levels

The growth in output and increase in the production portfolio means increase in variety for the customer and hence more customer satisfaction. It also means generation of more streams of revenue and profit. However there is need to watch out for overproduction which result in reduction of average prices and hence revenue and profit. The ineffectiveness of terms combining temporary and permanent workers emanated from the difference in both contract provisions and wages, whereas the same differences do not exist in the nature and size of tasks, resulting in perceptions of unfairness.

It was also found out that temporary workers had high levels of dissatisfaction, high turnover intentions and low commitment to Hunyani Matura Farm, agreeing with (Rousseau and Libuser, 1997:107, Wandera 2011:193). Despite the expense involved in the use of permanent employees, almost all of them indicated a high level of job satisfaction and zero turnover intention as evidenced by their positive ratings on working conditions.

\section{CONCLUSIONS}

Hunyani Matura Farm utilised permanent employment contract, fixed term contracts and casual work arrangements. The farm uses more of casual work arrangements than any other mode of employment. Workers employed under contract and casual employment modes had a higher level of job dissatisfaction than those who were on permanent mode of employment. Although temporary and casual workers had high intention to leave, the two categories had higher work output than their permanent counterparts, indicated by ability to complete their daily targets all times. The high labour turnover Hunyani Matura Farm had different implications continuity of agricultural operation. A change from permanent to temporary employment mode reduced the cost of production, increased profits, increased growth in sales revenue, scope of activities and market share. The Farm also became more productive both in terms of total area under production and yield per hectare.

\section{RECOMMENDATIONS}

Therefore, based on the findings of this study, the best combination of employment modes for Hunyani Matura Farm is one which involves:

- A few permanent employees who occupy key positions that require specially qualified and stable employees with high commitment and no intention to leave. This is because of their high level of stability and intention to stay. These positions should include people in supervisory positions, stores and requisition positions, employment record keeping and also the directors, since changing key management every three years is likely to result in disruptions to the equilibrium. 
- As many as needed more productive and cheaper casual workers to occupy the simple easy tasks which require no special skill or qualifications and which are flexibly hired, rotated and replaced.

- Seasonal contracts for supervisors of seasonal tasks that require specific knowledge and job experience. With reference to Hunyani Matura Farm, these take form of supervisors for specialised tasks like tobacco drying and grading. These should be employed to oversee the drying and grading of tobacco to train the casual workers taken in that regard. Attractive seasonal contracts should be drafted for these to enable Hunyani Matura Farm to get the best experienced candidates and minimise loss due to mistakes.

\section{ACKNOWLEDGEMENTS}

Special thanks goes to the Chinhoyi University of technology for giving the first author an attachment place, and free access to the workers during the data collection process.

\section{REFERENCES}

Huber, J. (1991). A theory of family, economy, and gender. In Gender, family, and economy: The triple overlap, edited by Rae L. Blumberg. Newbury Park, CA: Sage.

Ncube, M. (2000). Employment, unemployment and the evolution of labour policy in zimbabweZambezia (2000), XXVII (ii).

Aldrich, R., Crook, D. and Watson, D. (2000) Education and Employment: the DfEE and its Place in History. London: Institute of Education, University of London.

Allen, A., Howard, J., Jamison, A., Jayne, T., Kondo, M., Snyder, J., Yeboah, F. (2016). Agri-food Youth Employment and Engagement Study. Michigan State University Report. Retrieved from http:// www.isp.msu.edu/files/8114/6738/2393/AgYees_Report_FINAL_ web.pdf

Carolyn J. and Knight J. (2002). The Economic Decline of Zimbabwe, 2002.

Cascio, W.F. (1991), Applied Psychology in Personnel Management, Prentice Hall, Englewood Cliffs, NJ.

Chiripanhura B.M\&Makwavarara T. (2002) The Labour Market and Economic Developments 1980-2000, Zimbabwe Congress of Trade Union Publication 2002

Cohen, L. and Manion, L. (2005). Research Methods in Education: An introduction to Theory and Methods .5th ed. London: Rutledge.

Colase, 2009

Collins J L and Krippner G R. (2001). Permanent labour contracts in agriculture. Flexibility and subordination in a new export crop. Society for Comparative study of History. 1999. pp. 510-534

Constantine: Costa, G. J. M. \& Silva, N. M. A. (2007). "Knowledge management: how ethical is your organization's knowledge?" Proceedings of the ETHICOMP 2007, 2007, pp. 123-136.

CUT (2017). New developments at the Farm, Research, Teaching and Extension Unit Chinhoyi University of Technology. CUT weekly. 6/07/2016 päge 2-7

Filmer, D., \& Fox, L. (2014). Youth Employment in Sub-Saharan Africa. Africa Development Series. Washington, DC: The World Bank. Retrieved from https://openknowledge.worldbank.org/ bitstream/handle/10986/16608/9781464801075. Pdf

Fisher, M. J. (1948). Equal Pay for Equal Work Legislation. ILR Review Volume: 2 issue: 1, page(s): 50-57. Issue published: October 1, 1948. https://doi.org/10.1177/001979394800200103

GoZ (Government of Zimbabwe), (1995). Labour Act:28. Government Printers, Harare, Zimbabwe.

Harris M, Tang K and Tseng Y. (2002). Optimal Employee Turnover Rate: Theory and Evidence. Melbourne Institute Working Paper No. 19/02. ISSN 1328-4991 ISSN 1447-5863 2002 (Online)

International LabourOrganisation (1978), Labour Conditions and Discrimination in Southern Rhodesia (Zimbabwe) (Geneva ILO) 65 International Labour Organization (2015). Report for discussion at the Meeting of Experts on Non-Standard Forms of Employment (Geneva, 16-19 February 2015) / International Labour Office, Conditions of Work and Equality Department, Geneva, 2015. ISBN 978-92-2-129384-2.

Jayne, Thomas and Ameyaw, David Sarfo (2016) 'Africa's Emerging Agricultural Transformation: Evidence, Opportunities and Challenges', in AGRA (Alliance for a Green Revolution in Africa), Africa Agriculture Status Report Working Paper 9 | February 201851 2016: Progress Towards Agriculture Transformation in Sub-Saharan Africa, https://reliefweb.int/sites/reliefweb.int/ files/ resources/assr.pdf (accessed 24 January 2018)

Jensen, Michael C. and Richard R. (1983). The Market for Corporate Control: The Scientific Evidence. Journal of Financial Economics 11 pp. 5-50.

Kawulich B. B. (2005). Participant Observation as a Data Collection Method. Forum Qualitative Sozialforschung / Forum: Qualitative Social Research. Volume 6, No. 2, Art. 43 - May 2005

Maiyaki, A. A. (2010). Zimbabwe's agricultural industry Department of Business Administration, Bayero University, Kano, Kano State, Nigeria. Accepted 14 July, 2010

Mapolisa T. (2015).A Comparative Case Study of Zimbabwe's Public and Private Universities' staff Retention Strategies. Zimbabwe Open University 2015 pg. 118-120.

Nardone, T., Veum, J., Yates, J. (1997), "Measuring job security", Monthly Labor Review, Vol. 120 No.6, pp.26-33. Ngechu. M. (2004), Understanding the research process and methods. An introduction to research methods. Acts Press, Nairobi.

Nielen S. and Schiersch A. (2014). Temporary agency work and firm competitiveness: Evidence from German Manufacturing firms. Industrial relations: journal /of economy and society Vol. 53, Issue 3, pp. 365-393 2014.

Nollen, S.D.; Axel, H. 1996. Managing contingent workers: How to reap the benefits and reduce the risks. New York: Amacom.

Nonaka, I. \& Takeuchi, H. (1995). Knowledge-creating company: How Japanese companies create the dynamics of innovation. Oxford University Press, 1995.

Ongera R. M. \&Juma D. (Undated). Influence of Temporary Employment on Employee Performance: A Case Study of Safaricom Limited. Department of Business and Social Science School of Human Resource Development Jomo Kenyatta University of Agriculture and Technology. International Journal of Business and Commerce Vol. 4, No.04 [01-37] (ISSN: 2225-2436)

Parker, R.E. (1994), Flesh Peddlers and Warm Bodies: The Short term Help Industry and its Workers, Rutgers University Press, New Brunswick, NJ. Pearce

Pasurai F (2017). Is Zimbabwe becoming a gig economy? News Day 8/09/2017. < http://www.newsday.co.zw. Viewed 1st November 2017 
Rousseau, D. M. \&Libuser, C. (1997). Contingent workers in high risk environments. California Management Review, 39(2), 103-123.

Selby, A. (2005). Losing the Plot: The Strategic Dismantling of White Farming in Zimbabwe 2000-2005 2006. Centre for International Development, Queen Elizabeth House, Oxford. QEH Working Paper Series - QEHWPS143 Page 1 Working Paper Number 143

Smith, T. M. \& Reece, J. S. (1999). The relationship of strategy, fit, productivity, and business performance in a services setting. Journal of Operations Management, 17(2): 145-161.

Taylor, F. W. (1996). "The principles of scientific management." In J.M. Shafritz\& J.S. Ott (Eds.), Classics of organization theory (pp.66-79). Belmont, CA: Wadsworth Publishing Company.

Jayne T. S. and AmeyawD. (2016) Africa's Emerging Agricultural Transformation: Evidence, Opportunities and Challenges 2016. African Agriculture status report 2016

Ton Z \&Huckman R.S. (2008). Managing the Impact of Employee Turnover on Performance: The University of Science and Technology Wandera H. T. (2011). The effects of short term employment contract on an organization: a case of Kenya forest service. International Journal of Humanities and Social Science Vol. 1 No. 21 [Special Issue - December 2011] 184

Yeboah, K., and Jayne, T. S. (2016). Africa's Evolving Employment Structure. International Development Working Paper 148, East Lansing: Michigan State University

Zimbabwe Agricultural Statistics (2016). Agriculture and livestock survey in A1 farms, 2015. Zimbabwe National Statistics Agency, Harare. Zimbabwe.

Rousseau D. M. and LibuserC. (1997). Contingent Workers in High Risk Environments. Volume: 39 issue: 2, page(s): 103-123. https:// doi.org/10.2307/41165889

Sachikonye L. M. (2003) The Situation of Commercial Farm Workers in Zimbabwe after Land Reform A Report prepared for the Farm Community Trust of Zimbabwe (FCTZ), Harare 
